\title{
Pengaruh Pemberian Probiotik Terhadap Kandungan Protein Pada Pakan Komersial
}

\author{
Anshar Haryasakti ${ }^{1}$, Imanuddin ${ }^{2}$, dan Muhammad Hirwan Wahyudi ${ }^{3}$ \\ 1,2,3 Sekolah Tinggi Pertanian Kutai Timur, Sangatta, Kutai Timur, Kalimantan Timur \\ 1Email: haryasaktia@yahoo.com
}

\begin{abstract}
This study aimed to determine the effect of probiotics on nutrient content (protein) of commercial feed. The Research was conducted on June up to September 2017 for 3 months at the Aquaculture Laboratory of East Kutai Agricultural College and at the Fisheries Technology Laboratory of Fisheries and Marine Sciences Mulawarman University. The descriptive method was used in this research. The used samples were applied in 4 treatments, which were the treatments using $0 \mathrm{ml}, 6 \mathrm{ml}, 7 \mathrm{ml}$, and $8 \mathrm{ml} \mathrm{Em4}$ in each kilogram of feed. The results showed that the $7 \mathrm{ml} \mathrm{kg}^{-1}$ dose had given the highest value (10,14\%), followed by $8 \mathrm{ml} \mathrm{kg}{ }^{-1}$ of dose $(9,79 \%), 6 \mathrm{ml} \mathrm{kg}^{-1}(6.30 \%)$ and the lowest was $0 \mathrm{ml} \mathrm{kg}^{-1}(6.11 \%)$, respectively.

Keywords: Aquaculture, Commercial feed, Fish feed dose, Probiotics, Protein.
\end{abstract}

\begin{abstract}
ABSTRAK
Penelitian ini bertujuan untuk mengetahui pengaruh pemberian probiotik terhadap kandungan nutrisi (Protein) pakan komersial. Penelitian ini dilaksanakan pada Juni sampai dengan September 2017 selama 3 bulan bertempat di Laboratorium Akuakultur Sekolah Tinggi Pertanian Kutai Timur dan di Laboratorium Teknologi Hasil Perikanan Fakultas Perikanan dan IImu Kelautan Universitas Mulawarman. Metode yang digunakan dalam penelitian ini adalah metode deskriptif. Sampel yang digunakan ada 4 perlakuan yaitu $0 \mathrm{ml}, 6 \mathrm{ml}, 7 \mathrm{ml}$, dan $8 \mathrm{ml}$ dosis EM4 dalam setiap kilogram pakan. Hasil penelitian menunjukkan bahwa dosis $7 \mathrm{ml} \mathrm{kg}^{-1}$ pakan memberikan nilai yang tertinggi $(10,14 \%)$, kemudian secara berturut-turut dosis $8 \mathrm{ml} \mathrm{kg}^{-1}$ pakan $(9,79 \%)$, dosis $6 \mathrm{ml} \mathrm{kg}^{-1}$ pakan $(6,30 \%)$ dan yang terendah adalah dosis $0 \mathrm{ml} \mathrm{kg}^{-1}$ pakan $(6,11 \%)$.

Kata kunci: Budidaya perikanan, Probiotik, Dosis pakan ikan, Protein, Pakan komersial.
\end{abstract}

\section{Pendahuluan}

Pakan salah satu faktor terpenting yang berpengaruh terhadap pertumbuhan dan kelangsungan hidup ikan yang akan dibudidaya. Pakan merupakan biaya terbesar dalam suatu sistem budidaya mencapai 40-60\% dari biaya produksi (Sahwan, 2004). Pada budidaya ikan secara intensif, pakan merupakan komponen biaya produksi yang paling tinggi yaitu $60 \%-70 \%$ dari biaya operasional. Hal ini disebabkan karena tingginya harga bahan baku pakan yang sampai saat ini sebagian besar masih diimpor.

Salah satu cara yang dapat ditempuh untuk meningkatkan efisiensi pakan agar mudah dicerna adalah dengan penambahan probiotik dalam pakan buatan (Haetami, 2008). Putra (2010) menyatakan bahwa dalam meningkatkan nutrisi pakan, bakteri yang terdapat dalam probiotik memiliki mekanisme dalam menghasilkan beberapa enzim untuk pencernaan pakan seperti amylase, protease, lipase dan selulose. Enzim tersebut yang akan membantu menghidrolisis pakan (molekul kompleks), seperti memecah karbohidrat, 
protein dan lemak menjadi molekul yang lebih sederhana dengan mempermudah proses pencernaan dan penyerapan dalam saluran pencernaan ikan.

Effective Microorganisme 4 (EM4) mengandung berbagai mikroorganisme yang bermanfaat, yaitu Laktobacillus yang bermanfaat untuk memfermentasi bahan organik menjadi senyawa asam laktat, bakteri fotosintetik yang berfungsi menyerap gas-gas beracun dan panas dari proses fermentasi, ragi (yeast) yang mempunyai peran dalam memfermentasi bahan organik menjadi senyawa alkohol, gula dan asam amino dan Actinomycetes yang berfungsi untuk menghasilkan senyawa antibiotik yang bersifat toksik terhadap bakteri patogen dan mampu melarutkan ion-ion fosfat dan ion-ion mikro lainnya (Wididana, 1996). Jenis probiotik komersial yang dijual bebas di pasar umumnya dominan mengandung bakteri Lactobacillus. Bakteri ini merupakan salah satu mikroorganisme dalam proses fermentasi, yang apabila terdapat dalam bahan makanan atau pakan, akan dapat meningkatkan kecernaan pakan dan pertumbuhan ikan membantu salah satu jenis probiotik yang tersedia di pasaran adalah EM4, probiotik ini mengandung bakteri Lactobacillus sp., Acetobacter sp., Streptomycetes sp., dan Yeast. Beberapa kandungan nutrisi yang dibutuhkan ikan yaitu protein, lemak dan karbohidrat, untuk menghemat pemberian pakan maka dilakukan penelitian Pemberian probiotik terhadap kandungan protein pakan dengan bantuan probiotik.Tujuan penelitian ini adalah untuk mengetahui pengaruh pemberian probiotik (EM4) terhadap kandungan protein pakan komersil, serta mengetahui dosis probiotik yang terbaik.

\section{Metodologi Penelitian}

\section{Waktu dan Tempat}

Penelitian ini dilaksanakan pada tanggal Juni sampai dengan 1 September 2017 selama 3 bulan bertempat di Laboratorium Budidaya Perairan Sekolah Tinggi Pertanian Kutai Timur, dan di Laboratorium Teknologi Hasil Perikanan Fakultas Perikanan dan IImu Kelautan Universitas Mulawarman, Samarinda.

\section{Rancangan Penelitian}

Penelitian ini menggunakan metode deskriptif. Parameter yang diuji adalah perbedaan dosis probiotik komersial EM4 pada pakan. Dosis probiotik yang diberikan terdiri atas 4 perlakuan. Perlakuan yang diuji sebagai berikut :

1. Perlakuan $\mathrm{A}=0 \mathrm{ml}$ EM4/kg pakan

2. Perlakuan $B=6 \mathrm{ml} \mathrm{EM} 4 / \mathrm{kg}$ pakan

3. Perlakuan $\mathrm{C}=7 \mathrm{ml}$ EM4/kg pakan

4. Perlakuan $\mathrm{D}=8 \mathrm{ml}$ EM4/kg pakan 


\section{Alat dan Bahan}

Alat yang digunakan untuk penelitian ini dapat dilihat pada tabel berikut :

Tabel 1. Alat yang Digunakan Untuk Penelitian

\begin{tabular}{|c|c|c|c|}
\hline No & Nama Alat & Jumlah & Fungsi \\
\hline 1 & Toples & 4 buah & Sebagai wadah pakan yang akan diteliti \\
\hline 2 & Tissue & - & Untuk membersihkan alat \\
\hline 3 & Kamera & - & Untuk dokumentasi \\
\hline 4 & Spektrofometer Visible (Labu) & 1 unit & Untuk destruksi hasil protein \\
\hline 5 & Tabung Reaksi & 8 buah & Untuk mereaksikan larutan \\
\hline 6 & Tabung Kjehdahl & 4 buah & Tempat bahan yang akan diendapkan \\
\hline 7 & Pemanas Kjehdahl & 1 unit & Digunakan untuk memanaskan suatu zat \\
\hline 8 & Alat distilasi & 1 unit & Untuk keperluan destilasi \\
\hline 9 & Buret $50 \mathrm{ml}$ & 1 buah & $\begin{array}{l}\text { Memberikan secara tetes demi tetes sejumlah } \\
\text { volume larutan yang diketahui dengan teliti pada } \\
\text { proses titrasi }\end{array}$ \\
\hline 10 & Erlenmeyer $250 \mathrm{ml}$ & 4 buah & Untuk menampung larutan yang akan dititrasi \\
\hline 11 & Spatula & 2 buah & Untuk mengaduk larutan \\
\hline 12 & Kertas timbang & & Untuk menimbang zat padat \\
\hline 13 & Batu didih & 15 buah & $\begin{array}{l}\text { Untuk meratakan panas dan untuk menghindari titik } \\
\text { lewat didih }\end{array}$ \\
\hline 14 & Gelas ukur $25 \mathrm{ml}$ & 1 buah & $\begin{array}{l}\text { Sebagai tempat penimbangan zat dan tempat } \\
\text { larutan }\end{array}$ \\
\hline 15 & Pipet tetes & 2 buah & Digunakan untuk mengambil larutan \\
\hline 16 & Corong gelas & 1 buah & Untuk menyaring suatu zat \\
\hline
\end{tabular}

Bahan yang digunakan untuk penelitian dapat dilihat pada tabel 2 berikut ini:

Tabel 2. Bahan yang Digunakan Untuk Penelitian

\begin{tabular}{cl}
\hline No & \multicolumn{1}{c}{ Nama Bahan } \\
\hline 1 & Probiotik \\
2 & Pakan komersial \\
3 & Aquades \\
4 & Larutan $\mathrm{H}_{2} \mathrm{SO}_{4}$ pekat \\
5 & Garam Kjehdahl \\
6 & Larutan Asam Borat \\
7 & Larutan Protein Standar \\
\hline
\end{tabular}

\section{Prosedur Penelitian}

Prosedur penelitian dilakukan dengan 2 tahapan yaitu tahap persiapan yang terdiri dari proses pembuatan pakan probiotik dan tahap pelaksanaan penelitian, yang terbagi menjadi penelitian pendahuluan yaitu pengujian pakan di Laboratorium Konsentrasi Budidaya Perairan, sebelum dikirim ke Laboratorium Teknologi Hasil Perikanan Fakultas Perikanan dan IImu Kelautan Universitas Mulawarman dan penelitian lanjutan. Proses pemberian probiotik dilakukan dengan mencampurkan probiotik tersebut pada pakan komersial dengan cara campurkan probiotik dan pakan komersial yang telah dihaluskan dan difermentasi selama 12 jam kemudian dikirimkan ke laboratorium.

\section{Penelitian Terdahulu}

Penelitian pendahuluanyaitu pengujian pakan di Laboratorium Budidaya Perairan, Sekolah Tinggi Pertanian Kutai Timur, sebelum dikirim ke Laboratorium Teknologi Hasil 
Perikanan Fakultas Perikanan dan IImu Kelautan Universitas Mulawarman. Penelitian pendahuluan ini dilakukan untuk mengetahui berapa lama waktu yang dibutuhkan dalam proses fermentasi sampai sampel pakan rusak dengan cara:

1. Persiapan alat dan bahan yang digunakan seperti wadah berupa toples, pakan, gelas ukur dan aquades

2. Pakan yang digunakan dihaluskan sebanyak $1 \mathrm{~kg}$ kemudian masukkan ke dalam wadah. Mencampurkan $100 \mathrm{ml}$ aquades dengan $7 \mathrm{ml}$ probiotik

4. Campuran aquades dan probiotik dimasukkan kedalam wadah yang berisi pakan dan aduk sampai rata

5. Menutup wadah rapat dan melakukan pengamatan terhadap kerusakan pakan (jamur akan tumbuh pada pakan)

\section{Persiapan Uji Pakan}

Prosedur pembuatan pakan sampel/uji yakni :

1. Pakan uji ditimbang, wadah fermentasi pakan uji disiapkan sebanyak 4 buah, lalu dimasukkan ke dalam wadah toples masing-masing 1.000 gram

2. Masing-masing probiotik yang akan digunakan ditambahkan ke dalam wadah yang telah disiapkan, sesuaikan dengan perlakuan

3. Tutup rapat toples dan dibiarkan selama 12 jam

4. Bahan uji yang telah difermentasi kemudian dilakukan uji kandungan nutrisi (protein) di laboratorium

\section{Pengujian Kandungan Protein Dengan Metode Kjehdahl}

Pengujian kandungan protein dengan metode Kjehdahl dilakukan dengan 3 tahap yakni :

1. Destruksi

Sampel dan garam kjehdahl ditimbang lalu dimasukkan ke dalam labu destruksi. $\mathrm{H}_{2} \mathrm{SO}_{4}$ pekat $20 \mathrm{ml}$ dan batu didih dimasukkan ke dalam labu destruksi dan merangkai alat destruksi. Proses destruksi dilakukan sampai warna larutan dalam labu biru bening. Larutan didinginkan, lalu $100 \mathrm{ml}$ aquades dicampurkan.

2. Destilasi

$\mathrm{NaOH}$ 30\% dimasukkan kedalam alat destilasi. Labu destruksi dipasang pada alat destilasi. Memasangkan destilasi yaitu berupa asam borat 2\% $100 \mathrm{ml}$ yang ditambahkan indikator campuran. Larutan $\mathrm{NaOH} 30 \%$ ditambahkan hingga volumenya mencapai $\pm 200 \mathrm{ml}$. Tutup aliran $\mathrm{NaOH}$ kemudian steam dinyalakan. Destilasi berjalan sampai destilat bervolume $200 \mathrm{ml}$. Steam dimatikan kemudian buka aliran keluar untuk mengeluarkan $\mathrm{NaOH}$. 


\section{Titrasi}

Larutan $\mathrm{HCl}$ disiapkan dalam buret dan bakukan dengan larutan boraks. Titrasi destilat dengan menggunakan $\mathrm{HCl}$. Titik akhir titrasi ditunjukkan dengan warna merah muda.

\section{Hasil dan Pembahasan}

Hasil pengujian kandungan protein pada pakan komersil yang diberikan perlakuan probiotik, dapat dilihat pada tabel 3.

Tabel 3. Hasil Penelitian Pengaruh Pemberian Probiotik Terhadap Kandungan Nutrisi (protein) Pada Pakan Komersial

\begin{tabular}{|c|c|c|}
\hline Perlakuan & Dosis Probiotik & Protein Total (\%) \\
\hline $\begin{array}{l}\text { A } \\
B \\
C \\
D\end{array}$ & $\begin{array}{l}0 \mathrm{ml} \text { EM4 } \mathrm{kg}^{-1} \text { pakan } \\
6 \mathrm{ml} \text { EM4 } \mathrm{kg}^{-1} \text { pakan } \\
7 \mathrm{ml} \text { EM4 } \mathrm{kg}^{-1} \text { pakan } \\
8 \mathrm{ml} \text { EM4 } \mathrm{kg}^{-1} \text { pakan }\end{array}$ & $\begin{array}{c}6,11 \\
6,30 \\
10,14 \\
9,79\end{array}$ \\
\hline
\end{tabular}

Pada tabel 3 dapat dilihat bahwa pemberian probiotik terhadap kandungan nutrisi

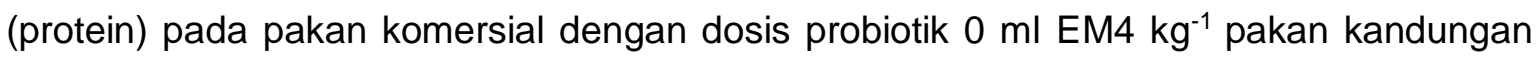

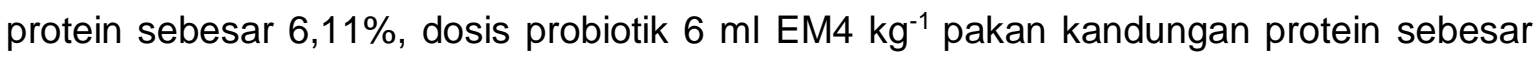
$6,30 \%$ dan dosis probiotik $7 \mathrm{ml}$ EM4 $\mathrm{kg}^{-1}$ pakan kandungan proteinnya 10,14\% dan pada dosis probiotik $8 \mathrm{ml} \mathrm{EM4} \mathrm{kg}^{-1}$ pakan proteinnya adalah 9,79\%.

Hasil penelitian menunjukkan bahwa peningkatan kandungan protein tertinggi diperoleh pada perlakuan $\mathrm{C}$, kemudian perlakuan $\mathrm{D}$, perlakuan $\mathrm{B}$ dan yang terendah pada perlakuan A. Tingginya peningkatan protein pada perlakuan C disebabkan adanya kandungan bakteri pada probiotik yang mampu mengurai senyawa komplek menjadi sederhana, hal ini sesuai dengan Wang et.al., (2008) yang menyatakan bahwa bakteri probiotik menghasilkan enzim yang mampu mengurai senyawa kompleks menjadi sederhana sehingga siap digunakan. Bakteri yang terdapat dalam probiotik memiliki mekanisme dalam menghasilkan beberapa enzim untuk pencernaan pakan seperti amylase, protease, lipase dan selulosa dalam meningkatkan nutrisi pada pakan, hal yang sama juga dikemukakan oleh Arief et.al., (2008) yang menyatakan bahwa enzim pencernaan akan membantu menghidrolisis nutrien pakan (molekul kompleks), seperti memecah karbohidrat, protein dan lemak menjadi molekul yang lebih sederhana yang akan mempermudah pencernaan dan penyerapan dalam saluran pencernaan ikan.

Widyawati (2015), menyatakan bahwa bakteri Lactobacillus sp. yang merupakan bakteri asam laktat memiliki sistem proteolitik yang mampu menghidrolisis protein makanan menjadi peptida dan asam amino. Lactobacillus sp memiliki komponen utama yang berfungsi sebagai pemecah protein yaitu enzim serine protease (PrtP).Kenaikan nilai protein diduga akibat dari proses fermentasi yang dilakukan pada pakan selama penelitian, 
bakteri yang terkandung dalam probiotik mampu untuk menghidrolisis pakan, karena pada fermentasi pakan mampu memotong rantai peptida protein dari rantai panjang protein, bakteri akan memanfaatkan protein, sehingga bakteri akan berkembang di pakan (substrat), pemanfaatan serat oleh bakteri selulolitik dan diubah menjadi protein.

Irianto (2007), menyatakan bahwa bakteri pada probiotik mampu mensekresikan enzim-enzim pencernaan seperti protease dan amilase sehingga mampu mengoptimalkan daya cerna pakan. Hal yang sama juga dikemukakan oleh Putra (2010), melaporkan bahwa penambahan probiotik dalam pakan telah meningkatkan jumlah populasi bakteri dibandingkan dengan perlakuan lainnya, sehingga diduga menyebabkan aktivitas enzim dalam pencernaan dan kecernaan pakan meningkat. Beberapa probiotik telah digunakan pada kegiatan akuakultur dan telah berperan dalam meningkatkan pertumbuhan, tingkat kelangsungan hidup, kecernaan, efisiensi pakan, sistem kekebalan tubuh dan komposisi bakteri yang menguntungkan (probiotik) dalam saluran pencernaan ikan. Selain itu, diduga penyebab lainnya pada perlakuan C (7 ml probiotik) bakteri probiotik mampu memberikan kinerja positif dalam menghasilkan enzim-enzim yang berfungsi sebagai pemecah nutrien menjadi senyawa yang lebih sederhana (protein) sehingga mengoptimalkan penyerapan nutrien pakan pada saluran pencernaan, selanjutnya bakteri tersebut didalam saluran pencernaan ikan akan mensekresikan enzim-enzim pencernaan seperti protease dan amilase (Irianto, 2003). Lebih lanjut, bakteri tersebut dapat mendominasi di saluran pencernaan ikan dan bakteribakteri patogen akan berkurang keberadaannya sehingga ikan akan memanfaatkan bakteri baik tersebut untuk tumbuh dan ikan menjadi sehat.

Enzim yang disekresikan ini jumlahnya meningkat juga sesuai dengan jumlah dosis probiotik yang diberikan pada pakan. Peningkatan daya cerna bermakna pula pada semakin tingginya nutrien yang tersedia untuk diserap tubuh, sehingga protein tubuh dan pertumbuhan meningkat, agar pakan dimanfaatkan secara optimal maka dibutuhkan aktivitas bakteri dalam pencernaan yang masuk melalui pakan yang menyebabkan terjadinya keseimbangan jumlah bakteri dalam usus sehingga dapat menekan bakteri patogen. Menurunnya tingkat efisiensi pakan pada dosis $8 \mathrm{ml} / \mathrm{kg}$ pakan diduga akibat terlalu tingginya populasi bakteri sehingga menimbulkan persaingan pertumbuhan bakteri Bacillus sp. dalam pengambilan nutrisi atau subtrat yang pada akhirnya menghambat aktivitas bakteri di dalam saluran pencernaan ikan sehingga sekresi enzim pun menurun (Gatesoupe, 1999).

Hasil penelitian yang diperoleh ini sama dengan yang didapatkan oleh Mansyur dan Tangko (2008), menyatakan bahwa penambahan probiotik pada pakan dapat meningkatkan nilai protein dan kadar air sedangkan untuk lemak, abu dan serat kasar menurun, tetapi dengan semakin tingginya dosis probiotik yang diberikan pada pakan nilai tersebut menurun, hal yang sama juga dilaporkan oleh Arief (2008), bahwa pemberian 
pakan dengan penambahan probiotik mampu meningkatkan kandungan gizi nilai protein dan menurunkan serat kasar pada pakan. Kemampuan probiotik ini menjadi salah satu penyebab turunnya nilai protein pada pakan seperti yang diperoleh selama penelitian dimana pakan yang diberi probiotik $8 \mathrm{ml} / \mathrm{kg}$ pakan nilai kandungan protein setelah proses fermentasi mengalami penurunan menjadi $9,79 \%$.

\section{Kesimpulan}

Kesimpulan dari penelitian ini yaitu pemberian probiotik pada pakan komersial berpengaruh terhadap kandungan nutrisi (protein) tetapi tingginya dosis probiotik tidak menjamin tingginya kandungan protein dalam pakan komersial. Dosis probiotik yang memberikan peningkatan nutrisi tinggi dari semua perlakuan yaitu $7 \mathrm{ml} / \mathrm{kg}$ pakan dengan peningkatan kandungan protein sebesar $10,14 \%$.

\section{Daftar Pustaka}

Arief, M., Kusumaningsih, E., \& Rahardja, B. S. (2008). Kandungan Protein Kasar Dan Serat Kasar Pada Pakan Buatan yang Difermentasi Dengan Probiotik. Berkala IImiah Perikanan, 3(2), 1-3.

Gatesoupe, F. J. (1999). The Use Of Probiotics In Aquaculture. Aquaculture, 180(1-2), 147165.

Haetami. (2008). Studi Pembuatan Probiotikbas (Bacillus licheniformis, Aspergillus niger, dan Sacharomices cereviceae) Sebagai Feed Suplement serta Implikasinya Terhadap Pertumbuhan Ikan Nila Merah. Laporan Penelitian. Fakultas Perikanan dan IImu Kelautan. Universitas Padjajaran.

Irianto, A. (2003). Probiotik akuakultur. Yogyakarta: Gadjah Mada University Press.

Irianto, A. (2007). Potensi Mikroorganisma: di Atas Langit Ada Langit. Ringkasan Orasi IImiah. Fakultas Biologi Universitas Jenderal Sudirman.

Mansyur, A., \& Tangko, A. M. (2008). Probiotik: Pemanfaatannya Untuk Pakan Ikan Berkualitas Rendah. Media Akuakultur, 3(2), 145-149.

Putra, A. N. (2010). Kajian probiotik, prebiotik dan sinbiotik untuk meningkatkan kinerja pertumbuhan ikan nila (Oreochromis niloticus). Bogor: Institut Pertanian Bogor.

Sahwan, M. F. (2002). Pakan Ikan dan Udang: Formulasi, Pembuatan, Analisis Ekonomi. Penebar Swadaya.

Wang, Y. B., \& Han, J. Z. (2007). The Role of Probiotic Cell Wall Hydrophobicity In Bioremediation of Aquaculture. Aquaculture, 269(1-4), 349-354.

Wididana, G. N., Riyatmo, S. K., \& Higa, T. (1996). Tanya jawab teknologi effective microorganism. Jakarta: INKPS dan PT. Songgolangit Persada.

Widyawati. (2015). Pengaruh Pemberian Pakan Berprobiotik Pada Populasi Mikroba Dalam Air dan Kadar Protein dalam Sedimen yang Ditetapkan Berdasarkan Hasil Pengembangan Metode comasier, serta Pengaruhnya Pada Pertumbuhan Lobster Air Tawar (Cherax quadricarinatus). Skripsi. Fakultas Farmasi. Yogyakarta: Universitas Sanata Dharma. 